\title{
Effectiveness of Basic Physics II Practicum Guidelines Based On Science Process Skills
}

\author{
Darmaji $^{1}$, Dwi Agus Kuriawan ${ }^{2}$, Ai Suryani ${ }^{3}$ \\ Physics Education Study Program, Faculty of Teacher Training and Education, Jambi \\ University, Jambi, Indonesia \\ darmaji@unja.ac.id ${ }^{1}$, dwiagus.k@unja.ac.id ${ }^{2}$, suryania096@gmail.com³
}

Received: August $5^{\text {th }}, 2018$. Revised: August $14^{\text {th }}, 2018$. Accepted: August $27^{\text {th }}, 2018$

\section{Keywords :}

Science Process Skills; Physics

Education Students;

Refraction; Practicum

Guidelines

\begin{abstract}
The Jambi University Physics Education Study Program has developed a Basic Physics II practicum guidelines based on science process skills that valid and reliable. However, there has not been a large scale implementation to determine the effectiveness of the guidelines. The purpose of this study was to determine the mastery of student science process skills after using the Basic Physics II practicum guidelines based on science process skills on refraction subject mater. This research is a quantitative research type of pre-experimental design with the OneShot Case Study. The research sample was the Physics Education second year students of Jambi University, amounting to 87 people. Data collection is done by observing using observation sheets about science process skills. Data were analyzed using descriptive statistics. The results showed that students were very good at mastering science process skills after using practicum guidelines based on science process skills. Percentage of mastery of science process skills for refraction practicum on parallel plan glass including: observation 64.84\%; experimental planning: $64.84 \%$; prediction $61.54 \%$; conducting experiment 53.85\%; measuring $49.45 \%$ and variabel identification $28.57 \%$. On average, students were very good at mastering science process skills in refraction practicums in prisms with their respective percentages: planning experiments $61.54 \%$; prediction $58.24 \%$; observation 48.35\%; conducting experiment 45.05\%; measuring $39.56 \%$ and identifying variables $32.97 \%$.
\end{abstract}

\section{INTRODUCTION}

Education is an ongoing process that aims to increase the quality of human resources. Formal education in Indonesia starts from primary education, secondary education and tertiary education [1]. Universities as a form of higher education provide various scientific faculties, one of them is the 
Teaching and Education Faculty (FKIP). The physics education study program is part of FKIP, aiming to create graduates who are experts in the aspects of knowledge, skills and attitudes.

Skills that must be mastered by physics teacher candidates must be in sync with the needs when teaching [2]. It is intended that students when they become teachers can teach effectively and efficiently [3]. The skills that help students during teaching include science process skills. Science process skills are thinking skills to form knowledge with the aim of solving problems and obtaining results [4].

Science process skills have two categories, basic science process skills and integration science process skills [5]. Basic science process skills are the basic skills used to carry out scientific inquiry. Basic science process skills consist of observation, conclusion, measuring, communication, classification, and prediction [6]. Integrated science process skills can be mastered after mastering basic process skills. Integration science process skills include: controlling variables, defining variables, making hypotheses, planning experiments, processing and interpreting experimental data [7]. Integration science process skills have strong relevance to practical activities and applications of science in life [8].

Students who have science process skills can practice understanding the concepts they have acquired in learning activities [9]. In addition to applying concept understanding, process skills can also be used to find problem solving. Science process skills can be used in scientific research to obtain scientific information and generalize it [10].

The teacher is a crucial part of the learning process, this is because the success of a learning is determined by how the teacher teaches [11]. A physics teacher who does not have Science Process Skills will teach students traditionally. Teachers who teach using traditional methods make students unable to form integration skills [12]. Students will study passively and cannot construct their knowledge independently [13]. Thus if a prospective teacher does not have process skills, it will certainly have an impact on the student knowledge development [14].

Considering the importance of the role of the teacher and the science process skills in learning activities, the prospective physics teacher students are forced to master science process skills [15]. Science process skills can be effectively developed by familiarizing students with practicum activities [16]. This is because almost all indicators of science process skills are available in the practicum [17]. Practicum will be implemented well if it is equipped with practicum instructions [18] [19]. The purpose of this study was to determine the science process skills of the second year students of Jambi University Physics Education after using the Basic Physics II practicum guidelines based on science process skills on refraction subject mater.

\section{METHOD}

This research is a quantitative research with Pre-experimental design, with One-Shot Case Study [20]. The following is the research design in Figure 1.

$$
\mathrm{X} \quad \mathrm{O}
$$

Fig 1. One Shot Case Study research design

Description:

$\mathrm{X}$ : treatment (independent variable)

O: observation (dependent variable) 
Based on Figure 1, the experimental class was given a treatment in the form of giving a practicum guide based on science process skills, then observing it. The sampling technique in this study is total sampling technique, because the population is less than 100 people [21]. The study sample consisted of 87 physics education students who contracted Basic Physics II. The data collection technique used is by observing student science process skills using the Observation Sheet (OS). OS is effectively used to assess science process skills [22]. The science process skills seen in this practicum are limited to indicators of observation, measuring, predicting, identifying variables, planning experiments and conducting experiments. In addition, interviews and documentation were also carried out to supplement quantitative data from observations of students' Science Process Skills. Students' Science Process Skills data were analyzed using descriptive statistics. Then, to find out the mastery of Science Process Skills by students will be grouped into 4 criteria, as in Table 1.

Table 1. Criteria for Students' Mastering Science Process Skills

\begin{tabular}{ccc}
\hline No & Interval & Category \\
\hline 1 & $25,00 \%-43.75 \%$ & Very Not Good (VNG) \\
2 & $43.76 \%-62.5 \%$ & Not Good (NG) \\
3 & $62.51 \%-81.25 \%$ & Good (G) \\
4 & $81.26 \%-100,00 \%$ & Very Good (VG) \\
\hline
\end{tabular}

\section{RESULTS AND DISCUSSIONS}

Based on the results of descriptive analysis, students' science process skills mastery after using the Basic Physics II practicum guidelines based on science process skills in refraction subject mater is very good. In accordance with research conducted by Prasetyo, microbiology practicum guides based on science process skills effectively increase students' participation and process skills mastery during practicum [23]. The basic science process skills observed were: observation, measuring, and prediction. While the integrated science process skills observed include: identifying variables, planning experiments and conducting experiments.

Table 2. Descriptive Analysis Results

\begin{tabular}{cclcccccc}
\hline $\begin{array}{c}\text { Science } \\
\text { Process } \\
\text { Skills }\end{array}$ & Indicator & Practicum & Min & Max & Range & Mean & STD & SEM \\
\hline Basic & Observation & Parallel & 45,00 & 100,00 & 55,00 & 86,67 & 12,12 & 1,30 \\
& & plan & & & & & & \\
& & Prism & 37,50 & 100,00 & 62,50 & 82,47 & 14,48 & 1,55 \\
& Measuring & $\begin{array}{l}\text { Parallel } \\
\text { plan }\end{array}$ & 29,17 & 100,00 & 70,83 & 80,65 & 16,82 & 1,80 \\
& & Prism & 33,33 & 100,00 & 66,67 & 74,29 & 18,02 & 1,93 \\
& Prediction & Parallel & 25,00 & 100,00 & 75,00 & 82,33 & 25,97 & 2,78 \\
& & plan & & & & & & \\
Integrated & Prism & 25,00 & 100,00 & 75,00 & 80,03 & 28,24 & 3,03 \\
& Identifying & Parallel & 25,00 & 100,00 & 75,00 & 66,19 & 24,65 & 2,64 \\
& variables & plan & & & & & & \\
& Planning an & Parallel & 25,00 & 100,00 & 75,00 & 68,77 & 23,44 & 2,51 \\
& experiment & plan & & 100,00 & 75,00 & 83,91 & 14,53 & 1,56 \\
& Prism & 41,67 & 100,00 & 58,33 & 84,00 & 12,53 & 1,34 \\
& Conducting & Parallel & 50,00 & 100,00 & 50,00 & 84,77 & 11,80 & 1,26 \\
& an experiment & plan & & & & & & \\
& Prism & 36,11 & 100,00 & 63,89 & 80,11 & 16,12 & 1,73 \\
\hline
\end{tabular}


Based on Table 2, it is known that the average of student's science process skills mastery is on the indicator observing 86.67 for refraction practicum on parallel plan glass and on the indicator planning 84.00 experiment for refraction practicum on prism. The average score of science process skills mastering for refraction practicum on parallel plan glass is higher than for prismatic practicum in prism except for the experimental planning plan.

Table 3. Science Process Skills Mastery

\begin{tabular}{|c|c|c|c|c|}
\hline \multirow{2}{*}{$\begin{array}{c}\text { Science } \\
\text { Prcess } \\
\text { Skills }\end{array}$} & \multirow[b]{2}{*}{ Indicator } & \multirow[b]{2}{*}{ Category } & \multicolumn{2}{|c|}{ Percentage } \\
\hline & & & Parallel plan & Prism \\
\hline \multirow[t]{12}{*}{ Basic } & Observation & VNG & $4.40 \%$ & $6.59 \%$ \\
\hline & & NG & $3.30 \%$ & $9.89 \%$ \\
\hline & & G & $27.47 \%$ & $35.16 \%$ \\
\hline & & VG & $64.84 \%$ & $48,35 \%$ \\
\hline & Measuring & VNG & $7.69 \%$ & $9.89 \%$ \\
\hline & & NG & $9.89 \%$ & $19.78 \%$ \\
\hline & & G & $32.97 \%$ & $30.77 \%$ \\
\hline & & VG & $49.45 \%$ & $39.56 \%$ \\
\hline & Prediction & VNG & $14.29 \%$ & $20.88 \%$ \\
\hline & & NG & $14.29 \%$ & $4.40 \%$ \\
\hline & & G & $9.89 \%$ & $16.48 \%$ \\
\hline & & VG & $61.54 \%$ & $58.24 \%$ \\
\hline \multirow[t]{12}{*}{ Integrated } & Identifying & VNG & $25.27 \%$ & $21.98 \%$ \\
\hline & variables & NG & $23.08 \%$ & $15.38 \%$ \\
\hline & & $\mathrm{G}$ & $23.08 \%$ & $29.67 \%$ \\
\hline & & VG & $28.57 \%$ & $32.97 \%$ \\
\hline & Planing an & VNG & $6.59 \%$ & $5.49 \%$ \\
\hline & experiment & NG & $4.40 \%$ & $4.40 \%$ \\
\hline & & G & $24.18 \%$ & $28.57 \%$ \\
\hline & & VG & $64.84 \%$ & $61.54 \%$ \\
\hline & Conducting & VNG & $4.40 \%$ & $7.69 \%$ \\
\hline & experiments & NG & $4.40 \%$ & $13.19 \%$ \\
\hline & & G & $37.36 \%$ & $34.07 \%$ \\
\hline & & VG & $53.85 \%$ & $45.05 \%$ \\
\hline
\end{tabular}

Based on Table 3, it is known that overall, students have mastered very well every indicator of science process skills, both basic and integrated. Percentage of mastery of science process skills in defining variables on parallel plans $28.57 \%(\mathrm{VG})$, and $32.97 \%(\mathrm{VG})$ in prisms. Mastery of science process skills in refraction practicum on parallel plan glass is higher than the percentage of mastery of science process skills in refraction practicum in prism.

Students have been very skilled in conducting observations with a percentage of mastery for refraction practicum on parallel plan glass $64.84 \%$ (VG) and $48.35 \%$ (VG) for refraction practicum on prisms. This situation is in accordance with the results of research conducted by Hamdani, who stated that observation is a basic skill that is relatively easier for students to master than integrated science process skills [24]. Observation is the skill of collecting data using the right five senses and can be supported by the right istruments [4]. Practicum guidelines are effective in helping students make observations. This is because students can make observations indirectly by looking at pictures of the istruments and materials available in the guidebook. Students also make direct observations by observing available istruments and materials. Because almost all science activities start from observation [25], then observation becomes a mandatory indicator for students to master. 
Measuring is a skill that requires students to take measurements using a measuring instrument to find quantitative and qualitative data from the measurement results [26]. On average, students have mastery skills that are very good with the percentage of mastery for refraction in parallel plan glass practicum $49.45 \%$ (SB) and $39.56 \%$ (SB) for refraction in prisms practicum. This is because students have mastered observation skills well, so that students have no difficulty mastering these skills. Students are interested in the experiments, so they tend to be active in measuring activities [27].

Prediction is a skill used to predict the consequences of changing circumstances based on previous treatment and observation [11]. Predictions in this study are carried out before students make prior observations. However, students can master the skills of predicting very well with the percentage of proposals for refraction practicum on parallel plan glass $61.54 \%$ (VG) and $58.24 \%$ (VG) for refraction in prisms. Practicum based on science process skills requires students to have good initial knowledge [28]. That is why students can predict well. Based on the interview results found that students can make predictions using laws or formulas related to practicum. "...I make predictions based on the identification of variables that are formulated, and also based on the refraction law..." (the interview was conducted on May 2, 2018).

Mastery of skills to identify variables for refraction practicum in parallel plan glass is distributed fairly evenly with the percentage of highs $28.57 \%$ in very good category. Whereas for the refraction practicum in prism, mastery of process skills is centered on very good category with a percentage of $32.97 \%$. Students still have difficulty identifying the variables well. Identifying variables is the skill of determining all independent variables, dependent variables, and control variables of events or situations [29]. Students are still not skilled at defining independent, bound and control variables.

Designing an experiment allows students to choose the tools and materials that will be used to investigate or prove the experimental hypothesis [30]. Based on the percentage of mastery of experimental designing skills, the average student has mastered the skill. Mastery of experimental planning skills for habituation of parallel and prismatic plan glass respectively $64.84 \%, 61.54 \%$ in very good category. The high mastery of students towards this experimental design skill is due to the high mastery of observation skills. Experiments are activities carried out to investigate hypotheses by manipulating independent variables, then interpreting the results of their relationship with the dependent variable [12]. Based on this, it can be concluded that experimentation is the highest skill among integration science process skills [13]. Students master the experimental skills very well, according to the percentage of students' mastery in the excellent category, 53.85\% for refraction practicums in parallel plans, and $45.05 \%$ for refraction practicums in prisms. In the experimental activity, students look more skilled in using tools and materials, taking data and concluding the results of the experiment [31]. Based on the results of interviews with several students, information was obtained that in the experimental activities students were greatly helped because the guidelines used were very systematic and easy to understand. A systematic practicum guideliens can help mastering experimental skills [26].

\section{CONCLUSION}

The conclusions form this study are:

1. Basic Physics II practicum guide based on science process skills on refraction material, effectively used to improve science process skills of observation, measuring, predicting, identifying variables, planning experiments, and conducting experiments..

2. The refracting practicum guidelines on parallel plan glass is more effective than the refraction practicum guidelines on prisms. 
Effectiveness of Basic Physics II Practicum Guidelines Based On... Darmaji, Dwi Agus Kuriawan, Ai Suryani

\section{REFERENCES}

[1] De Educacion. D. M. (2010). World Data on Education Donnees Mondiales de L'education Datos Mundiales de Educacion VII Ed. 2010/11. Education, 11, 2012.

[2] Rosdianto, H., \& Toifur, M. (2017). Implementasi Teori Distribusi Probabilitas Gaussian Pada Kualitas Rangkaian Penyearah Gelombang Penuh. Spektra: Jurnal Fisika dan Aplikasinya, 2(1): 83-90.

[3] Ayuningtyas, P., Soegimin, W. W., \& Supardi, Z. I. (2017). Pengembangan Perangkat Pembelajaran Fisika dengan Model Inkuiri Terbimbing untuk Melatihkan Keterampilan Proses Sains Siswa SMA pada Materi Fluida Statis. JPPS (Jurnal Penelitian Pendidikan Sains), 4(2): 636-647.

[4] Ozgelen, S. (2012). Students' Science Process Skills Within A Cognitive Domain Framework. Eurasia Journal of Mathematics, Science \& Technology Education, 8(4): 283-292.

[5] Hirça, N. (2017). Influence of Hands on Physics Experiments on Scientific Process Skills According to Prospective Teachers' Experiences. European Journal of Physics Education. 4 (1): $1-9$.

[6] Raj, R. G., \& Devi, S. N. (2014).Science Process Skills And Achievement In Science Among High School Students. Scholarly Research Journal for Interdisciplinary Studies, 2(15): 24352443.

[7] Chabalengula, V. M., Mumba, F., \& Mbewe, S. (2012). How Pre-Service Teachers' Understand And Perform Science Process Skills. Eurasia Journal of Mathematics, Science \& Technology Education, 8(3): 167-176.

[8] Karamustafaoğlu, S. (2011). Improving The Science Process Skills Ability Of Prospective Science Teachers Using I Diagrams. Eurasian Journal of Physics and Chemistry Education, 3(1): 26-38.

[9] Rosdianto, H. (2017). Penentuan Percepatan Gravitasi Pada Percobaan Gerak Jatuh Bebas Dengan Memanfaatkan Rangkaian Relai. Spektra: Jurnal Fisika dan Aplikasinya, 2(2): 107112.

[10] Aktamis, H., \& Ergin, Ö. (2008). The Effect Of Scientific Process Skills Education On Students' Scientific Creativity, Science Attitudes And Academic Achievements. Asia-Pacific Forum on Science Learning and Teaching, 9 (1): 1-21.

[11] Wiwin, E., \& Kustijono, R. (2018). The Use Of Physics Practicum to Train Science Process Skills And Its Effect on Scientific Attitude of Vocational High School Students. Journal of Physics: Conference Series, 997(1): 1-8.

[12] Zeidan, A. H., \&Jayosi, M. R. (2015). Science Process Skills and Attitudes toward Science among Palestinian Secondary School Students. World Journal of Education, 5(1): 13-24.

[13] Aydin, A. (2013). Representation of Science Process Skills in The Chemistry Curricula for Grades 10, 11 And 12/Turkey. International Journal of Education and Practice, 1(5): 51-63.

[14] Rosdianto, H. (2018). Rancang Bangun Alat Praktikum Gerak Jatuh Bebas Dengan Stopwatch Otomatis Sederhana. JIPF (Jurnal Ilmu Pendidikan Fisika), 3(2): 20-23.

[15] Mutisya, S. M., Rotich, S., \& Rotich, P. K. (2013). Conceptual understanding of science process skills and gender stereotyping: a critical component for inquiry teaching of science in Kenya's primary schools.

[16] Sumintono, M. B., Ibrahim, M. A., \& Phang, F. A. (2010). Pengajaran Sains Dengan Praktikum Laboratorium: Perspektif Dari Guru-Guru Sains SMPN Di Kota Cimahi. Jurnal Pengajaran MIPA, 15(2): 120-127.

[17] Siswono, H. (2017). Analisis Pengaruh Keterampilan Proses Sains Terhadap Penguasaan Konsep Fisika Siswa. Momentum: Physics Education Journal, 1(2): 83-90.

[18] Misbah, M., Wati, m., \& Rif'at, M. F. (2018). Pengembangan Petunjuk Praktikum Fisika Dasar I Berbasis 5M Untuk Melatih Keterampilan Proses Sains dan Karakter Wasaka. Jurnal Fisika FLUX, 15 (1): 26-30.

[19] Rosdianto, H., \& Toifur, M. (2011). Analisis Kualitas Rangkaian Penyearah Gelombang Penuh Melalui Kriteria Nilai Simpangan Baku. Seminar Nasional Sains dan Pendidikan Sains 2011, 1(2): 21-26. 
[20] Sugiyono. (2016). Metode Penelitian: Kuantitatif, Kuanlitatif, dan R\&D. Bandung: Alfabeta.

[21] Sugiyono. (2007). Metode Penelitian: Kuantitatif, Kuanlitatif, dan R\&D. Bandung: Alfabeta.

[22] Hindarto, N., \& Edie, S. S. (2013). Analisis Kebiasaan Bekerja Ilmiah Mahasiswa Fisika Pada Pembelajaran Mata Kuliah Praktikum Fisika Dasar. UPEJ Unnes Physics Education Journal, 2(1): 85-91.

[23] Prasetyo, M. M (2016). Penembangan Penuntun Praktikum Mikrobiologi Berbasis Keterampilan Proses Sains mahasiswa Pendidikan Biologi UIN. Jurnal Biotek, 4(1): 1-20.

[24] Hamdiyati, Y., \& Kusnadi, M. (2017). Profil Keterampilan Proses Sains Mahasiswa Melalui Pembelajaran Berbasis Kerja Ilmiah Pada Matakuliah Mikrobiologi. Jurnal Pengajaran MIPA. 10(2): 36-42.

[25] Ango, M. L. (2002). Mastery of Science Process Skills and Their Effective Use in the Teaching of Science An Educology of Science Education in the Nigerian Context. International Journal of Educology, 16(1): 11-30.

[26] Rauf, R. A. A., Rasul, M. S., Mansor, A. N., Othman, Z., \& Lyndon, N. (2013). Inculcation Of Science Process Skills In A Science Classroom. Asian Social Science, 9(8): 47-57.

[27] Ambarsari, W., Santosa, S., \& Maridi, M. (2013). Penerapan Pembelajaran Inkuiri Terbimbing Terhadap Keterampilan Proses Sains Dasar Pada Pelajaran Biologi Siswa Kelas VIII SMP Negeri 7 Surakarta. Jurnal Pendidikan Biologi, 5(1): 81-95.

[28] Deta, U. A., \& Widha, S. (2013). Pengaruh Metode Inkuiri Terbimbing dan Proyek, Kreativitas, serta Keterampilan Proses Sains terhadap Prestasi Belajar Siswa. Jurnal Pendidikan Fisika Indonesia, 9(1): 28-34

[29] Kilic, G. B., Haymana, F., \&bozyilmaz, B. (2008). Analysis Of The Elementary Science And Technology Curriculum Of Turkey With Respect To Different Aspects Of Scientific Literacy And Scientific Process. Egitm ve bilm. 33(150).

[30] Sani, R. A. (2016). Demonstrasi dan Eksperimen Fisika. Jakarta: Bumi Aksara

[31] Malik, A., Handayani, W., \& Nuraini, R. (2015). Model Praktikum Problem Solving Laboratory untuk Meningkatkan Keterampilan Proses Sains Mahasiswa. Prosiding Simposium Nasional Inovasi dan Pembelajaran Sains. ISBN: 978-602-19655-8-0 